\title{
A Simulation Study of Support Break-Off and Water Inrush during Mining under the High Confined and Thick Unconsolidated Aquifer
}

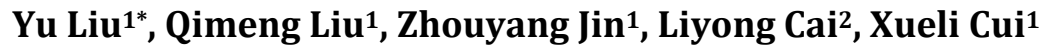 \\ ${ }^{1}$ School of Earth Science \& Environmental Engineering, Anhui University of Science \& Technology, \\ Huainan, China \\ ${ }^{2}$ Faculty of Engineering and Information Sciences, University of Wollongong, Wollongong, Australia \\ Email: *yuliu aust@163.com
}

Received 28 September 2014; revised 25 October 2014; accepted 20 November 2014

Copyright (C) 2014 by authors and Scientific Research Publishing Inc.

This work is licensed under the Creative Commons Attribution International License (CC BY). http://creativecommons.org/licenses/by/4.0/

(c) (7) Open Access

\begin{abstract}
The thick Cenozoic unconsolidated aquifer is deposited under Sunan syncline core in Huaibei coalfield, the water yield property of unconsolidated bottom aquifer is strong and water pressure is high in some areas (up to $4 \mathrm{MPa}$ in some areas). Water inrush accident often occurs during mining under unconsolidated aquifer, the biggest characteristic is abnormal mine pressure and support break-off during water inrush accident comparing with normal condition. In order to study mechanism of support break-off and water inrush during mining under the high confined thick unconsolidated aquifer, a simulation of similar material was designed. The experimental results indicated that, under normal condition, the compound breakage sequence of water-resisting key strata between coal seam and high confined thick unconsolidated aquifer is from top to bottom and the basic reason of synchronous fracture is the load of bottom key strata increased suddenly when the breakage of top key strata happened. Because of high confined thick unconsolidated aquifer, surface acts on the bottom key strata soil layer in the form of uniformly distributed load, which is the load-transfer mechanism of confined thick unconsolidated aquifer. Once the overlying key strata compound breaks, the height of unstable strata will reach far more than $\mathbf{3 0}$ meters and exceed support capability of current fully-mechanized mining supporter, which leads to support break-off accident during mining process under confined unconsolidated aquifer.
\end{abstract}

\section{Keywords}

Support Break-Off and Water Inrush, Simulation Experiment, Compound Breakage, Load Transfer

\footnotetext{
${ }^{*}$ Corresponding author.
}

How to cite this paper: Liu, Y., Liu, Q.M., Jin, Z.Y., Cai, L.Y. and Cui, X.L. (2014) A Simulation Study of Support Break-Off and Water Inrush during Mining under the High Confined and Thick Unconsolidated Aquifer. Open Journal of Geology, 4, 599-611. http://dx.doi.org/10.4236/ojg.2014.412044 


\section{Introduction}

Most of coalfield in North China are concealed coalfield covered by large-thick Cenozoic unconsolidated layers [1]. There is an aquifer in the bottom of unconsolidated layers consists of high permeability of unconsolidated sand and gravel where water yield property is good [2] [3]. The aquifer is directly hosted in the top of coal measures sandstone, commonly named as Fourth Aquifer or Bottom Aquifer. If the thickness of unconsolidated layers is great, the water pressure of the aquifer is normally high [1] [4] [5].

In recent years, there are dozens of water inrush accidents happened during coal mining practice under high confined unconsolidated aquifer in China [6] [7], which is a serious threat to coal mine safety production. There is always abnormally-increased roof pressure and even support break-off accidents happened accompanied with this kind of water inrush accident [8]. The roof pressure increased periodically with the advance of working face which shows that this kind of accident is not only associated with hydrogeology characteristics of high confined unconsolidated aquifer but also associated with structure types and the breakage characters of overburden strata [9]-[11]. The study of surrounding rock strata displacement and deformation is necessary technical foundation for studying coal mine water inrush mechanism and designing water control measures [8] [12].

Qidong coal mine, affiliated to the Anhui Hengyuan Coal and Electricity Co., Ltd, is located in the north of Huainan-Huaibei Coal Mine field [6] [7]. There were many water inrush accidents occurred during mining process under high confined unconsolidated aquifer. For instance, there was a support break-off and water inrush accident in 3222-Working Face, the first coal mining face of Qidong Coal Mine after construction. The water inrush accident led to coal mine being submerged and 36.48 million RMB in direct economic loss and the indirect economic loss was almost 100 million RMB. After recovery production, similar water inrush accidents occurred in 3221, 7114, 6130 and 7130 working faces which had a severe impact on safe and high-efficient exploitation of coal mine.

Similar-material simulation experiment is a way to study the laws of nature by utilizing the similar features between object or phenomena which is based on the Similarity Theory [13] [14]. It is not only suitable in such research fields that hard to obtain research results by theory approach, but also an effective means to analyze and compare research results [15]. The model was made according to a certain proportion of the actual rock strata by similar material based on Similarity Theory. We excavated the model on the basis of the actual mining method, then observed the displacement, deformation and failure of upper rock strata and obtained relevant parameters. Thus, we can analyze and infer the displacement and deformation laws of surrounding rock as the working face advances [13]. According to three laws of similarity, the major requirement is geometric similarity, motion similarity and dynamic similarity when two systems are similar. Coal mining condition under high confined thick unconsolidated aquifer was modeled based on similar material simulation experiment. We also obtained stress distribution law and roof displacement characteristics of surrounding rock strata, which provided technical support to further study of support break-off water inrush mechanism during mining under high confined thick unconsolidated aquifer.

\section{Design of Simulation Experiment}

\subsection{Experiment Objective}

The experiment objective is to study load-transfer mechanism of confined unconsolidated aquifer and laws of key strata compound breakage; compare and analyze the influence of confined unconsolidated aquifer on sequence of key strata breakage and explore the reason that support break-off water inrush often occurs during mining under confined aquifer.

\subsection{Model Prototype}

Research area topography is flat and surface elevation is $+21 \mathrm{~m}$ which located in the middle part of Huaibei Plain in Anhui Province. Hui river is a seasonal river and is the tributary of Huaihe river which flows through south part of coalfield. Sequence stratigraphy from top to bottom in the research area is Quaternary (Q), Neogene (N), Palaeogene (E), Cretaceous (K), Jurassic (J), Triassic $(\mathrm{T})$, Permain $(\mathrm{P})$, Carboniferous $\left(\mathrm{C}_{1+2}\right)$ and Ordovician $\left(\mathrm{O}_{1+2}\right)$. Carboniferous-permian is the main coal-bearing strata of Qidong coal mine. Coal-bearing strata are covered with Cenozoic unconsolidated layers which belong to concealed coalfield. Geological structure is comparatively simple in Qidong coal mine. There are three faults and monoclinal structure in research area. 
Occurrence of coal seam and rock stratum are different from West to East. The inclination of rock stratum turns from NNW trending to NNE trending. Fracture water of main coal seams' roof and floor sandstone is the direct source of water during mining. Main recharge of sandstone fracture water is infiltrate of unconsolidated aquifer in the bottom of Cenozoic. Thickness of Cenozoic unconsolidated layers is $350-375 \mathrm{~m}$ varying with ancient landform. Under the influence of neotectonic fault control and basin landform, thickness of Cenozoic unconsolidated layers become bigger and bigger from NE trending to SW trending. Lithology of research area consists of clay, sandy clay, clayey sand, silt, fine sand, medium sand and gravel, etc. The hydrogeological structure consists of multilayer of aquifers and water-resisting layers. The lithology and mechanical parameters of rock strata are shown in Table 1 [16]. According to the objective of experiment, the model prototype was designed, shown as Figure 1.

\subsection{Calculation of Similar Condition}

Geometrical scale: $\alpha_{l}=0.01$,

Poisson's ratio scale: $C_{\mu}=\mu_{m} / \mu_{p}=1$,

Volume weight scale: $\alpha_{\gamma}=\gamma_{m} / \gamma_{p}=0.6$,

Stiffness scale: $C_{E}=E_{m} / E_{p}=0.6$,

Stress scale: $\alpha_{R}=\alpha_{m} / \alpha_{p}=C_{E}=0.6$, and

Model time scale: $\alpha_{t}=0.1$.

where,

$\gamma_{p}$-Volume weight of actual rock strata, $\gamma_{m}$-Volume weight of rock strata in the model;

$\gamma_{m}$-Poisson's ratio of actual rock strata, $\mu_{m}$-Poisson's ratio of rock strata in the model;

$E_{p}$-Stiffness of actual rock strata, $E_{m}$-Stiffness of rock strata in the model;

$\alpha_{P}$-Stress of actual rock strata, $\alpha_{m}$-Stress of rock strata in the model.

\subsection{Experimental Equipment}

The experimental equipment consists of test bench, confined unconsolidated aquifer (bags, filled with water and sand) and water pressure control device, as shown in Figure 2.

Table 1. The lithology and mechanical parameters of rock strata in the model prototype.

\begin{tabular}{|c|c|c|c|c|c|c|c|c|}
\hline Lithology & $\begin{array}{c}\text { Volume } \\
\text { weight } / \mathrm{N} \cdot \mathrm{m}^{-3}\end{array}$ & $\begin{array}{l}\text { Rock strata } \\
\text { thickness/m }\end{array}$ & $\begin{array}{c}\text { Elasticity } \\
\text { modulus/GPa }\end{array}$ & $\begin{array}{l}\text { Poisson's } \\
\text { ratio }\end{array}$ & $\begin{array}{l}\text { Cohesion/ } \\
\mathrm{MPa}\end{array}$ & $\begin{array}{l}\text { Internal } \\
\text { friction } \\
\text { angle/( }\left(^{\circ}\right)\end{array}$ & $\begin{array}{c}\text { Strength of } \\
\text { extension/ } \\
\mathrm{MPa}\end{array}$ & Remark \\
\hline Key strata 2 & 25,000 & 8 & 60 & 0.4 & 40 & 40 & 7.0 & \multirow{6}{*}{$\begin{array}{c}\text { Thickness of } \\
\text { stratification } \\
\text { is } 2 \mathrm{~m}\end{array}$} \\
\hline Soft rock 2 & 25,000 & 8 & 10 & 0.3 & 30 & 30 & 1.0 & \\
\hline Key strata 1 & 25,000 & 8 & 60 & 0.4 & 40 & 40 & 7.0 & \\
\hline Soft rock 1 & 25,000 & 8 & 10 & 0.3 & 30 & 30 & 1.0 & \\
\hline Coal seam & 14,000 & 3 & 10 & 0.2 & 10 & 15 & 1.0 & \\
\hline Floor & 25,000 & 5 & 60 & 0.3 & 30 & 40 & 7.0 & \\
\hline
\end{tabular}

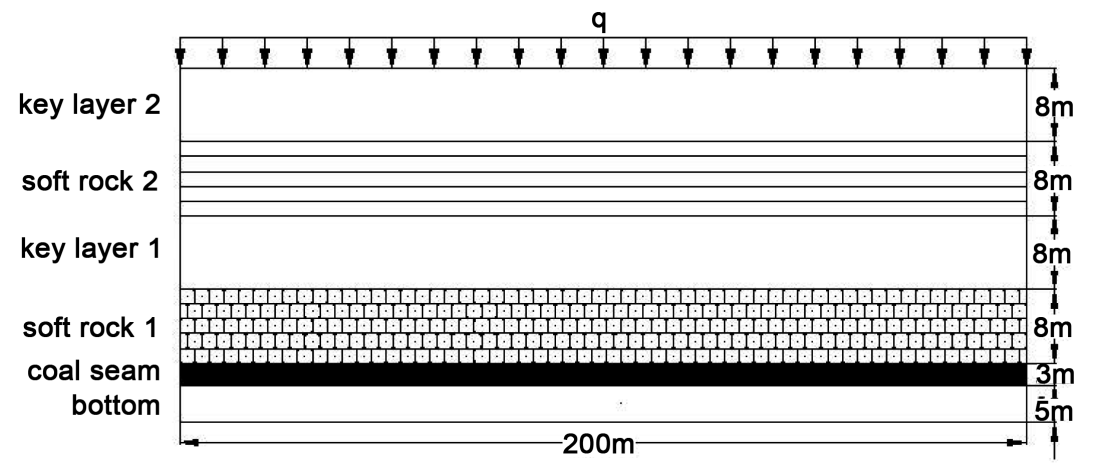

Figure 1. Similar simulation prototype graph. 


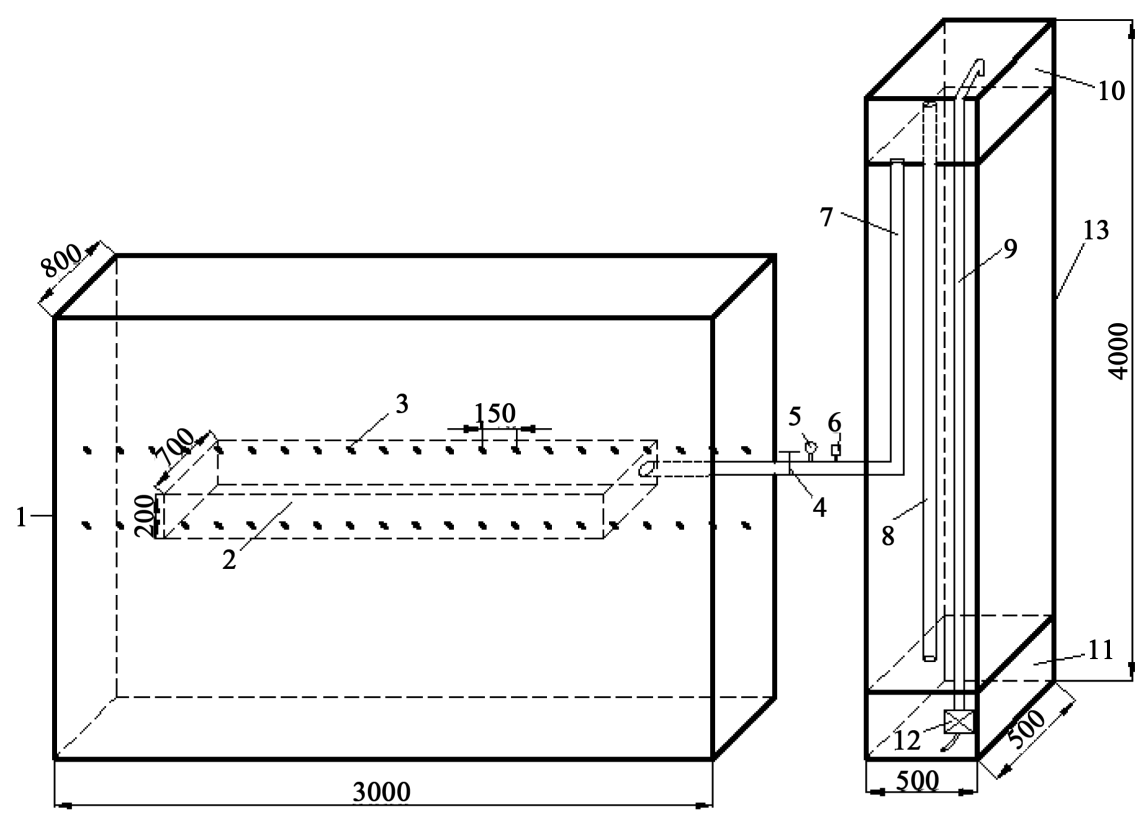

Simulation platform, 2-Bag be filled with water and sand (confined aquifer), 3-Pressure Sen-sor, 4-Valve, 5-Pressure gauge, 6-Pressure Sensors, 7-Injection Hose; 8-Overflow Hose; 9-Pipes up, 10-Upper tank, 11Pipes down, 12-Pumps, 13-Tank lifting frame

Figure 2. Test device of unconsolidated confined aquifer load transfer function (Unit: $\mathrm{mm}$ ).

Requirements of model equipment:

1) The major measuring instrument is pressure transducer and the sensitivity of pressure transducer and reliability of data gathering must be guaranteed. The sensitivity of pressure sensor must meet requirement of $1 \%$ and maximum value of $0.1 \mathrm{MPa}$.

2) The equipment need to be a high maneuverability. Water supply of pump has to reach $100 \mathrm{~L} / \mathrm{min}$.

3) Pressure transducers are put in the top and bottom surface of confined unconsolidated aquifer. The space between two pressure transducers is $150 \mathrm{~mm}$.

4) Injection hose, overflow hose and upper hose must be soft and total length should surpass the maximum height of tank lifting frame.

Program control static resistance strain gauge is used to transform pressure obtained by pressure transducers [17], computer is used to collect and save data, digital camera is used to shoot mining process of model and typical failure characteristics of model.

\subsection{Experimental Material}

Gypsum and lime were taken as cementing material in the experiment and gypsum is major. Sand, calcium carbonate, pulverized coal and water are the main material of coal seam and strata simulation. Ordinary river sand (particle size less than $1.5 \mathrm{~mm}$ ) is aggregate material and mica powder is layered material. Determining the amount of experimental material is based on type and volume of model material. Material ratio and amount of each rock strata are shown in Table 2.

\subsection{Experimental Schemes}

Determine the following three simulation project based on experiment objective.

\subsubsection{The First Simulation Project}

The first simulation project is used to study laws of key strata compound breakage under the uniform load $q$. We load by iron block and wooden tablet to assure the uniform load act on model. The mass of each iron block is $3.23 \mathrm{~kg}$ and the contact area with model is $0.02 \mathrm{~m}^{2}$. Thus the uniform load $q$ is $1.27 \times 10^{4} \mathrm{~Pa}$. The model simulation equipment based on similar simulation ratio is shown in Figure 3. 
Table 2. Material ratio and amount of each rock strata in simulation.

\begin{tabular}{|c|c|c|c|c|c|c|c|}
\hline $\begin{array}{c}\text { Rock } \\
\text { strata ID }\end{array}$ & Lithology & Thickness/cm & Sand/kg & Gypsum/kg & $\begin{array}{c}\text { Calcium } \\
\text { carbonate/kg }\end{array}$ & Water/kg & Pulverized coal $/ \mathrm{kg}$ \\
\hline 1 & Coal seam floor & 5 & 35.0 & 2.2 & 2.8 & 5.0 & \\
\hline 2 & Coal seam & 3 & 22.0 & 0.4 & 1.6 & 3.0 & \\
\hline 3 & Soft rock 1 & 10 & 66.7 & 4.0 & 9.3 & 10.0 & 1.5 \\
\hline 4 & Key strata 1 & 10 & 64.0 & 4.8 & 11.2 & 10.0 & \\
\hline 5 & Soft rock 2 & 10 & 66.7 & 4.0 & 9.3 & 10.0 & 1.5 \\
\hline 6 & Key strata 2 & 20 & 128.0 & 9.6 & 22.4 & 20.0 & \\
\hline
\end{tabular}

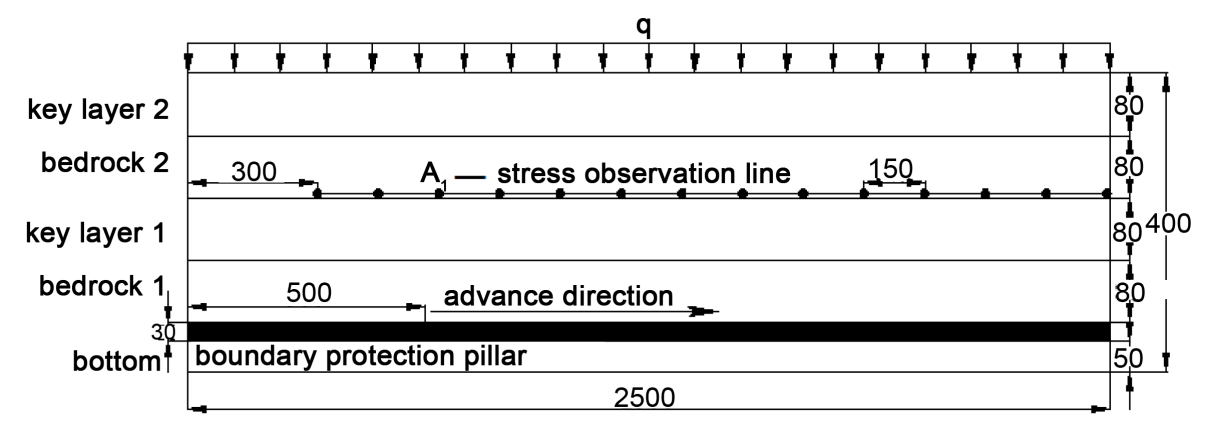

Figure 3. Schematic diagram of the test apparatus in Scenario 1 (Unit: mm).

Technical points:

1) Set a $500 \mathrm{~mm}$ protection pillar at mining boundary to eliminate boundary effect;

2) Put a stress observation line on the top surface of key strata 1 to observe load distribution and changing rule of stress. The particular arrangement of the pressure sensor above the observation line is shown in Figure 3.

\subsubsection{The Second Simulation Project}

The second simulation project is used to study load-transfer mechanism of confined unconsolidated aquifer. Thickness of surface soil is determined by uniform load in first simulation project, confined unconsolidated aquifer is put in the middle of surface soil and key strata 2. Transform the uniform load into surface soil with equivalent thickness on the basis of first simulation project. The volume weight of surface soil is $16 \mathrm{kN} \cdot \mathrm{m}^{-3}$; equivalent thickness is $80 \mathrm{~m}$ based on geometrical scale. Surface soil consists of sand, gypsum, calcium carbonate and water which were divided into 50 layers successively. Aggregate material of confined unconsolidated aquifer is composed of stones with comparatively bigger size particles. Constant water pressure of confined aquifer can be controlled by the height of water surface. Schematic diagram and photograph of model simulation equipment are shown in Figure 4 and Figure 5 respectively.

Technical points:

1) Keep water pressure of confined aquifer steady and the pressure head of confined should match to the thickness of surface soil.

2) Confined unconsolidated aquifer consists of aggregate material and water in the simulation, aggregate material is stones which particles with comparatively big size.

3) Put three stress observation lines in the area between key strata and confined unconsolidated aquifer to observe the relationship between stress distribution of top and bottom surface of aquifer by changing mining width.

\subsubsection{The Third Simulation Project}

The third simulation project is used to study breakage sequence of two key strata without influence of confined unconsolidated aquifer. To ignore the effect of load transfer, we put the surface soil on the key strata 2 directly. Thus, breakage sequence of each key stratum on that situation can be obtained. Schematic diagram of simulation equipment are shown in Figure 6. 


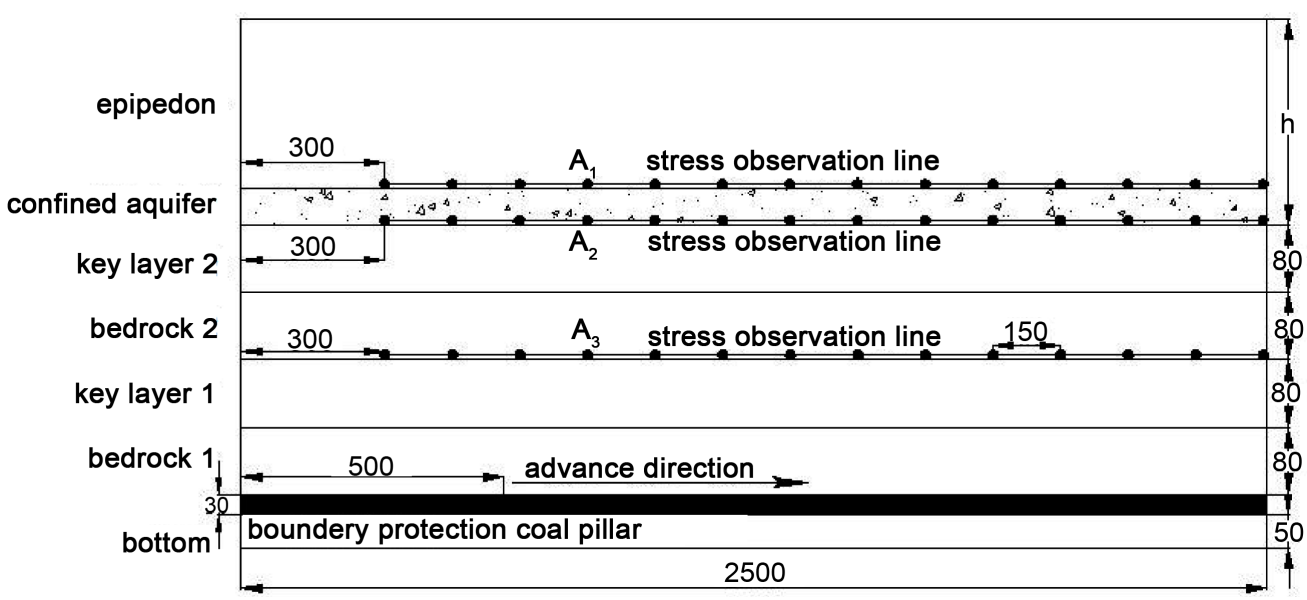

Figure 4. Schematic diagram of the test apparatus in Scenario 2 (Unit: mm).

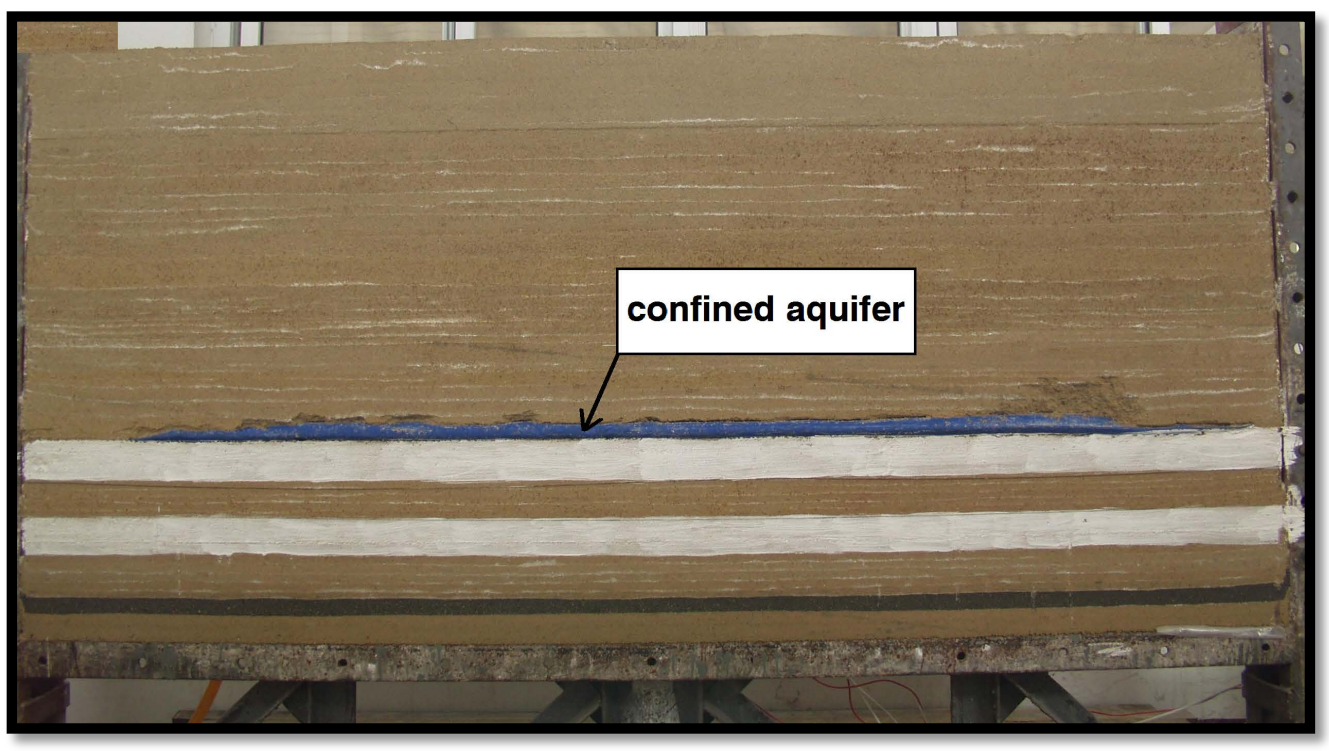

Figure 5. Scheme 2 similar model objective graph.

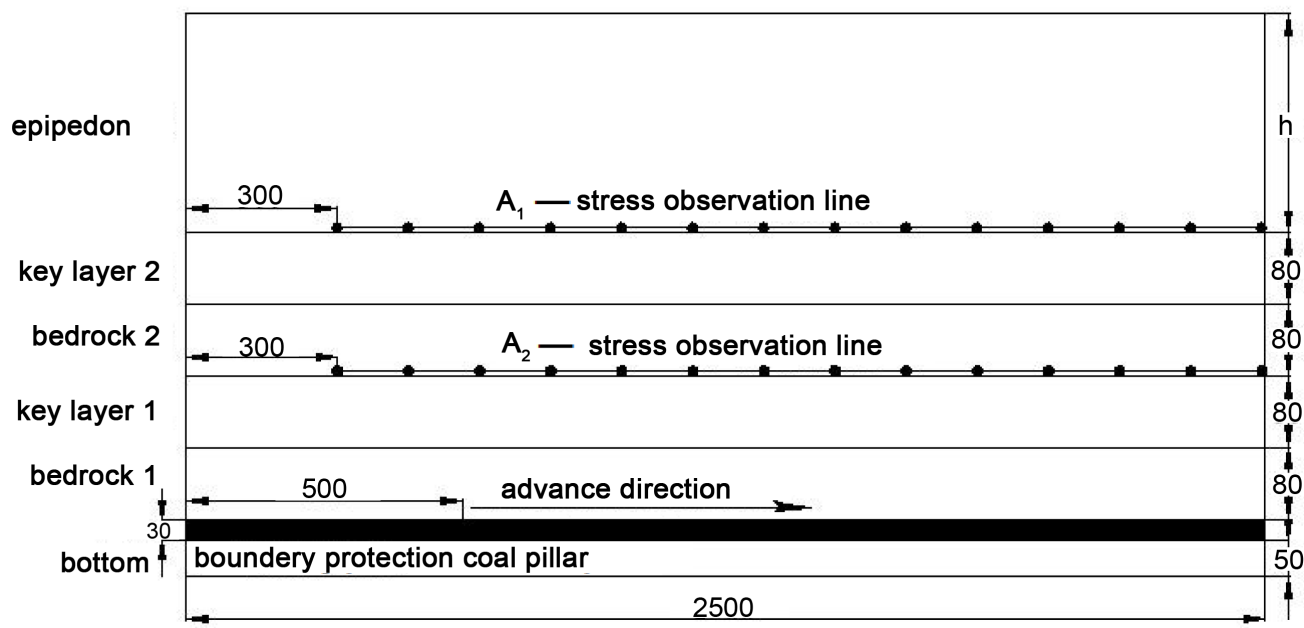

Figure 6. Schematic diagram of the test apparatus in Scenario 3 (Unit: mm). 


\section{Process and Result of Experiment}

\subsection{Process and Result of the First Simulation Project}

Key strata 1 and 2 fractured at the same time when the mining width reached $85 \mathrm{~cm}$ in the model. Fracture surface can be seen obviously (Figure 7). Data collection situation is different from each other with different mining widths (Table 3). Figure 8 describes the relationship between stress and data collection time at observation point, $70 \mathrm{~cm}$ away from the mining boundary.

Stress changes at measure point can be divided into the following four stages depending on mining width (Figure 8).

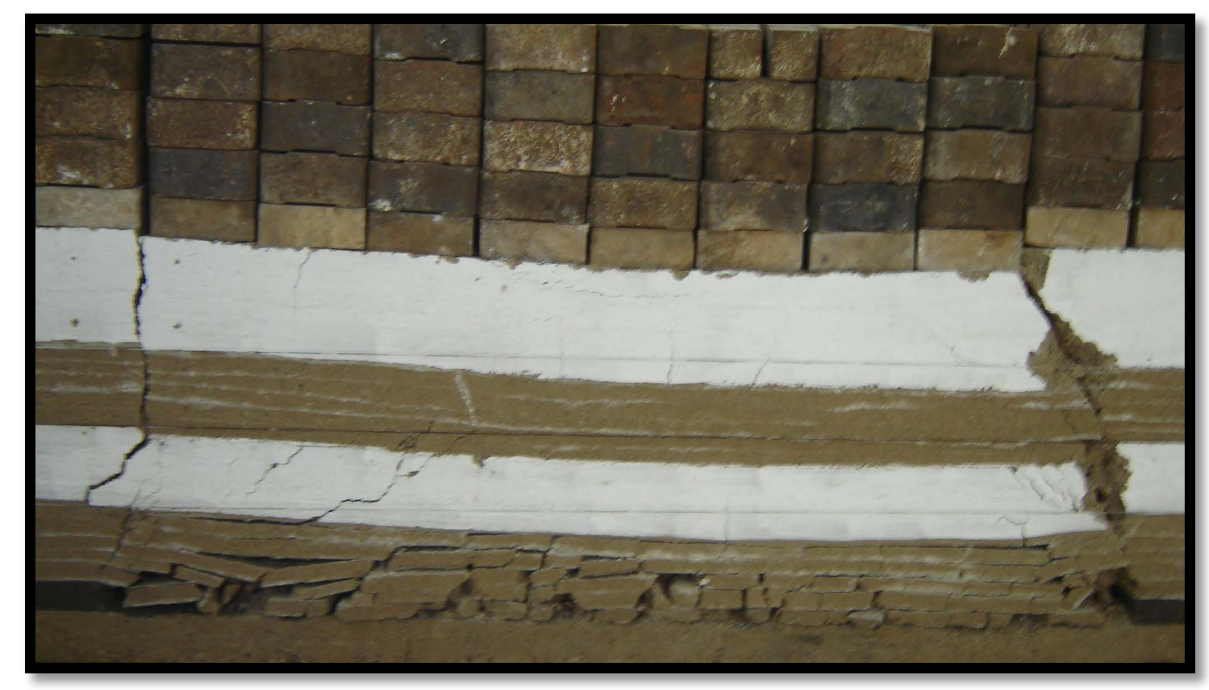

Figure 7. Key layer synchronization breaking in similar simulation.

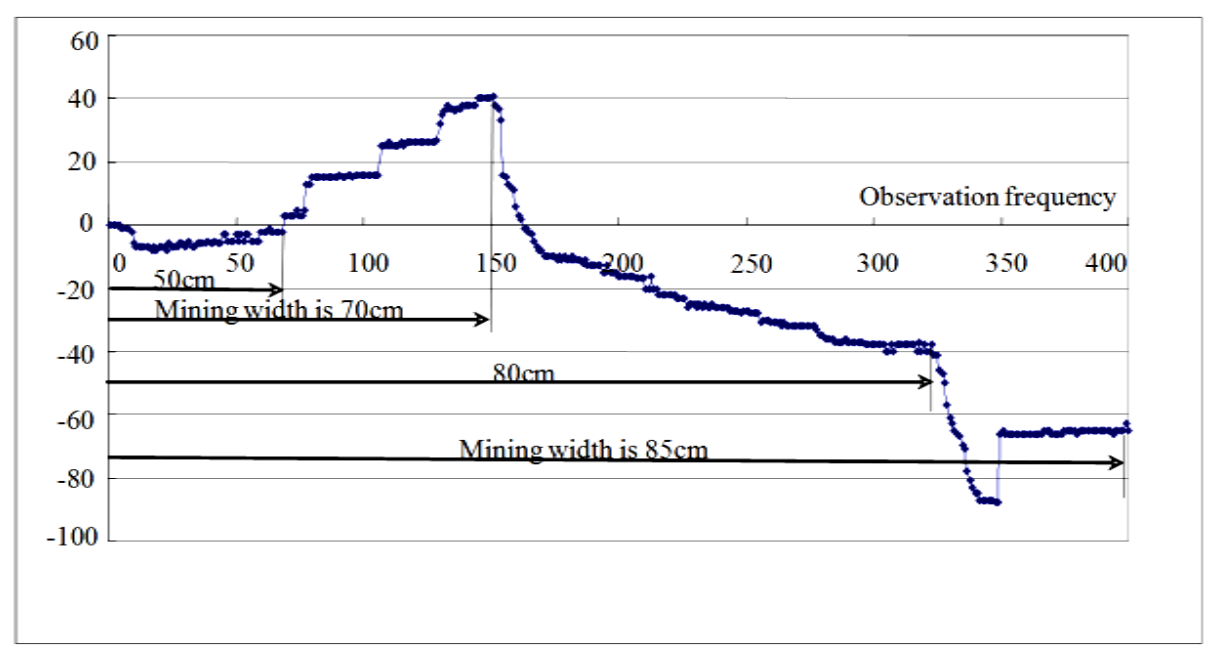

Figure 8. Stress changes at observation point, $70 \mathrm{~cm}$ away from the mining boundary.

Table 3. Distribute of data collection number with different mining width.

\begin{tabular}{cccccccc}
\hline Mining width/m & 10 & 20 & 25 & 30 & 35 & 40 & 45 \\
\hline Data collection number & $0-5$ & $6-10$ & $11-12$ & $13-34$ & $35-47$ & $48-59$ & $60-68$ \\
\hline Mining width/m & 50 & 55 & 60 & 70 & 80 & 85 & $332-400$ \\
\hline Data collection number & $69-76$ & $77-106$ & $107-128$ & $129-154$ & $155-331$ & 35 \\
\hline
\end{tabular}


The first stage: as mining width is between $0 \mathrm{~cm}$ and $50 \mathrm{~cm}$, stress at measure point remains the same, belongs to primary rock stress [18].

The second stage: as mining width is between $50 \mathrm{~cm}$ and $70 \mathrm{~cm}$, stress at measure point along with the mining width increases gradually, belongs to stress increase region.

The third stage: as mining width is between $70 \mathrm{~cm}$ and $80 \mathrm{~cm}$, stress at measure point decreases gradually, belongs to stress decrease region.

The fourth stage: mining width is $85 \mathrm{~cm}$, stress at measure point has a leap-growth based on the third stage.

Two key strata synchronous fracture happened because of roofing breaking interval in the fourth stage, the stress leap-growth at measure point is also the result of key strata breakage. From the aspect of macro behavior and variation of stresses at the moment of key strata breakage, mechanism of key strata compound breakage is top key strata break first, the reason of synchronous fracture is the load of bottom key strata increased suddenly as the breakage of top key strata.

\subsection{Process and Result of the Second Simulation Project}

Key strata 1 and 2 fractured at the same time when the mining width reached $90 \mathrm{~cm}$ in the model (Figure 9). Number of data collection is different with different mining width (as shown in Table 4). As Figure 10 shown that the relationship between stress and number of data collection at measure point of $95 \mathrm{~cm}$ to the mining boundary.

Figure 11 and Figure 12 showed the relationship between stress and number of data collection respectively at two measure points $70 \mathrm{~cm}$ to the mining boundary, at the top and bottom of confined unconsolidated aquifer.

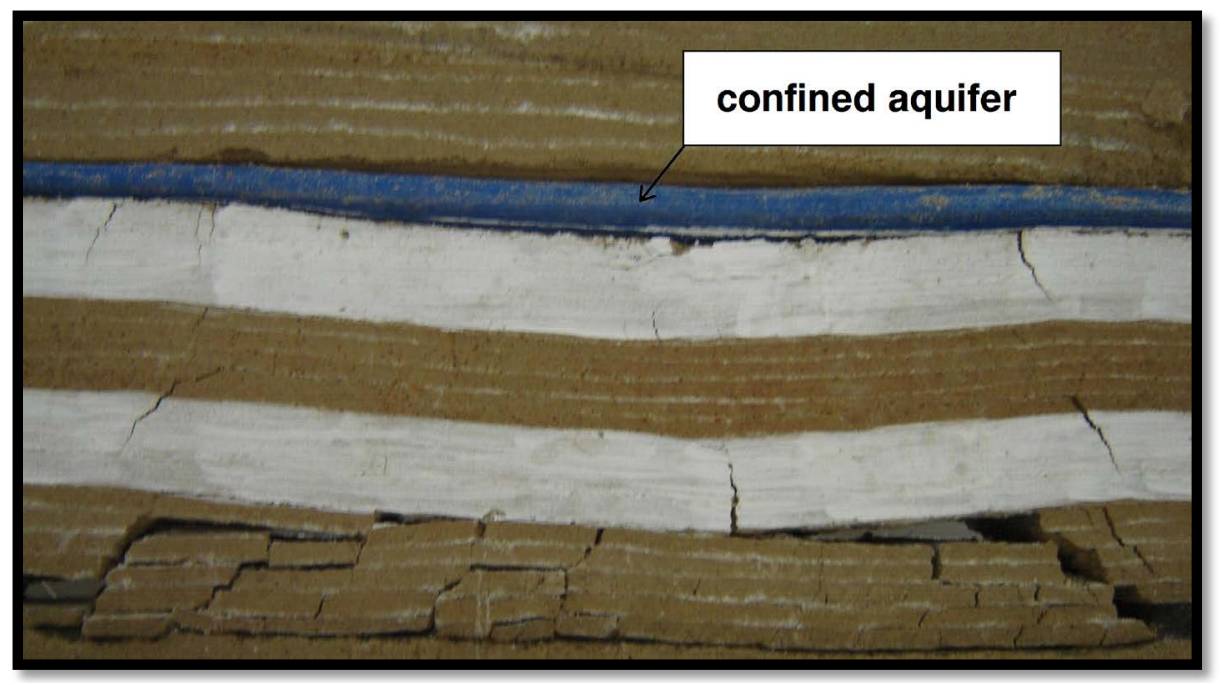

Figure 9. Key layer synchronization breaking in similar simulation.

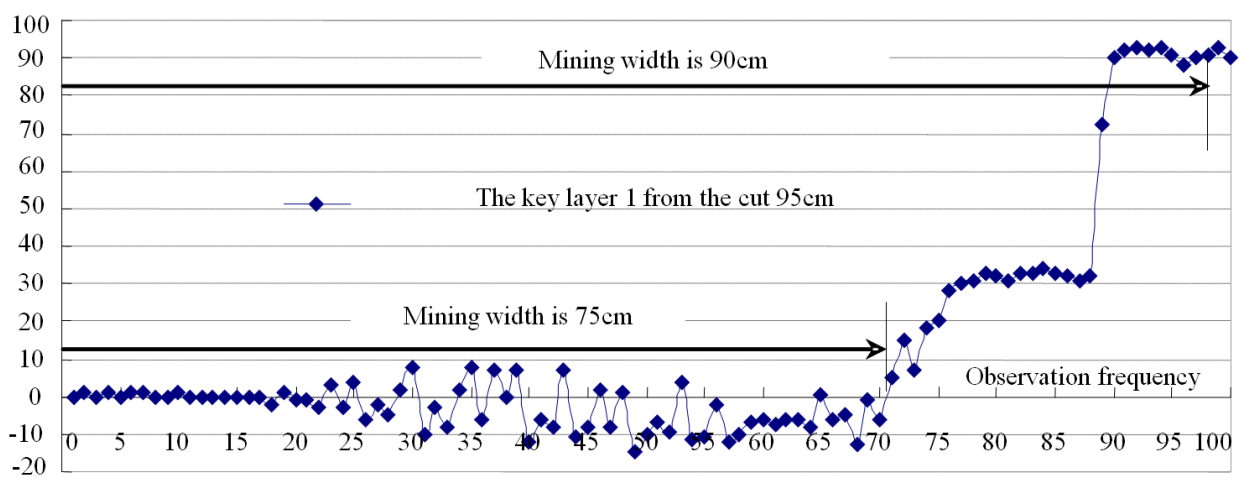

Figure 10. Stress changes at observation point, $95 \mathrm{~cm}$ away from the mining boundary. 
Table 4. Distribution of data collection number with different mining width.

\begin{tabular}{ccccccccc|}
\hline Mining width/m & 10 & 20 & 25 & 30 & 35 & 40 & 45 \\
\hline Data collection number & $1-18$ & $19-21$ & $22-26$ & $27-31$ & $32-36$ & $37-40$ & $41-48$ \\
\hline Mining width/m & 55 & 60 & 70 & 75 & 80 & 90 & \\
\hline Data collection number & $49-53$ & $54-62$ & $63-67$ & $68-73$ & $74-87$ & $88-98$ \\
\hline
\end{tabular}

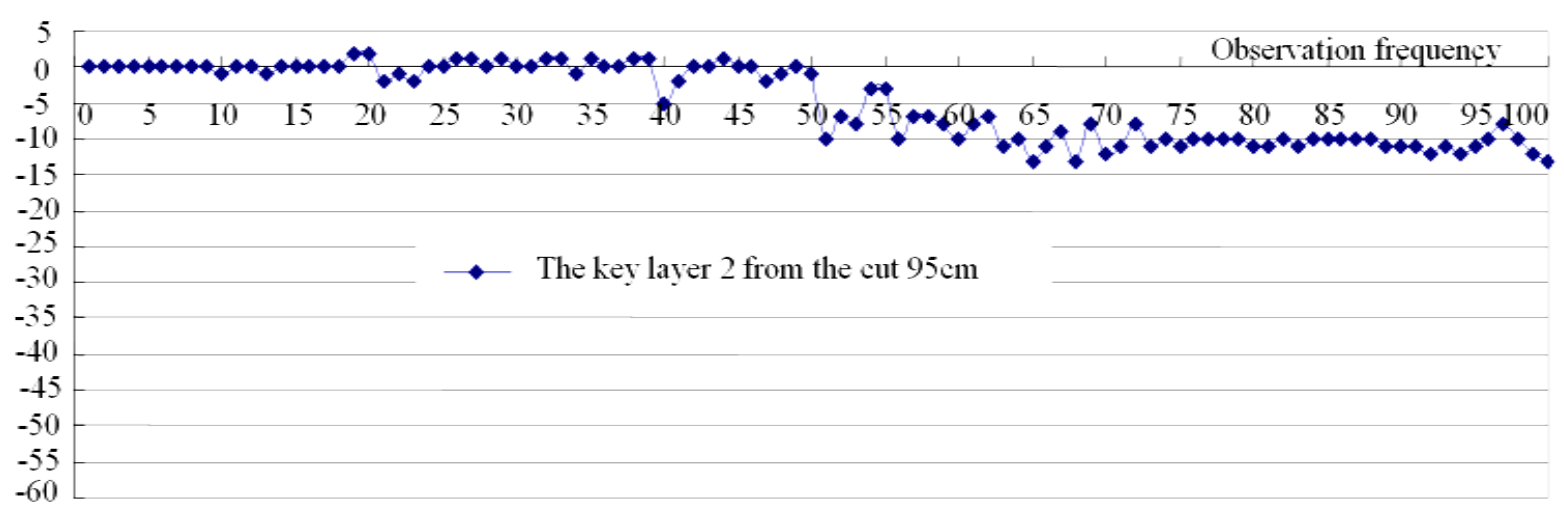

Figure 11. Stress changes at observation point, $70 \mathrm{~cm}$ away from the mining boundary.

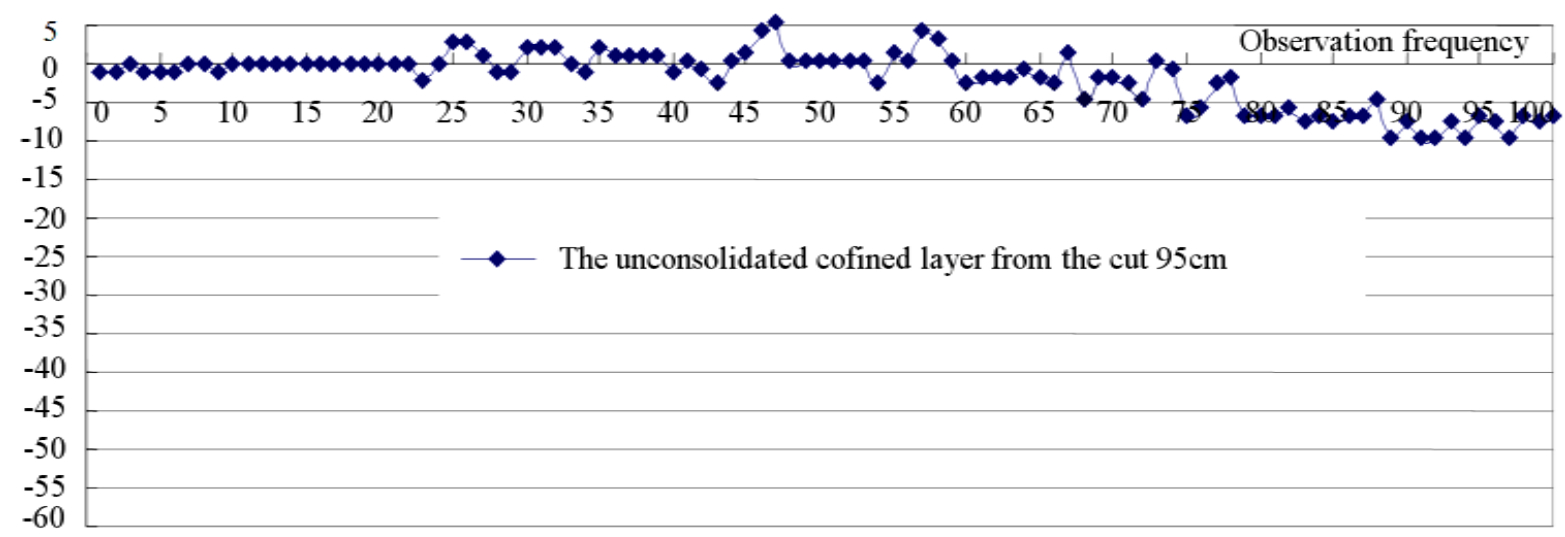

Figure 12. Stress change of observation points $70 \mathrm{~cm}$ away from mining boundary in unconsolidated confined aquifer.

Stress at the measure point $95 \mathrm{~cm}$ to the mining boundary can be divided into the following two stages depending on mining width.

The first stage: mining width is between $0 \mathrm{~cm}$ and $70 \mathrm{~cm}$, belonging to primary rock stress.

The second stage: as mining width is between $70 \mathrm{~cm}$ and $90 \mathrm{~cm}$, stress at measure point increases gradually and has a leap-growth at $90 \mathrm{~cm}$.

Breakage of key strata 2 resulted in load increases of key strata 1. According to primary roofing breaking interval of two key strata and relationship between stress and mining width at measure point on key strata 1, breakage of key strata belongs to compound breakage as well in Scenario 2.

With the influence of confined unconsolidated aquifer, surface soil and key strata stress are substantially free from the impact of mining width. There is no significant stress reduction or increase. Stress is a constant value.

The second simulation showed that with the existence of confined unconsolidated aquifer between surface soil and key strata, laws of key strata breakage are the same with the influence of uniform load. The type of breakage is still compound breakage and there is no obvious stress increase or decrease. Thus, we can conclude that with the existence of confined unconsolidated aquifer, load-transfer mechanism of confined unconsolidated aquifer is surface soil act as uniform load on bottom rock strata all the time. 


\subsection{Process and Result of the Third Simulation Project}

Key strata broke suddenly when the mining width reached $80 \mathrm{~cm}$ and surface soil and key strata 2 had no obvious changes. Key strata 2 broken and there was caving arch in surface soil when the mining width was up to $110 \mathrm{~cm}$. Distribution of data collection number with different mining widths is shown in Table 5.

Figure 13 shows the relationship between stress and mining width at measure point of $60 \mathrm{~cm}$ to the mining boundary. Figure 14 shows the relationship between stress and mining width at measure point of $75 \mathrm{~cm}$ to the open-off cut. Figure 15 shows the stress distribution of each measure points on the key strata 2 when mining width is $80 \mathrm{~cm}$, stress concentration and stress release emerged.

Figure 13 shows that relationship between stress and mining width can be divided into the following five stages:

Table 5. Distribution of data collection number with different mining width.

\begin{tabular}{cccccccc}
\hline Mining width/m & 10 & 20 & 25 & 30 & 35 & 40 \\
\hline Data collection number & $1-22$ & $23-51$ & $52-73$ & $74-113$ & $114-148$ & $149-170$ & $171-229$ \\
\hline Mining width/m & 60 & 65 & 75 & 80 & 90 & 100 \\
\hline Data collection number & $230-278$ & $279-356$ & $357-376$ & $377-419$ & $420-451$ & $452-469$ & $470-509$ \\
\hline
\end{tabular}

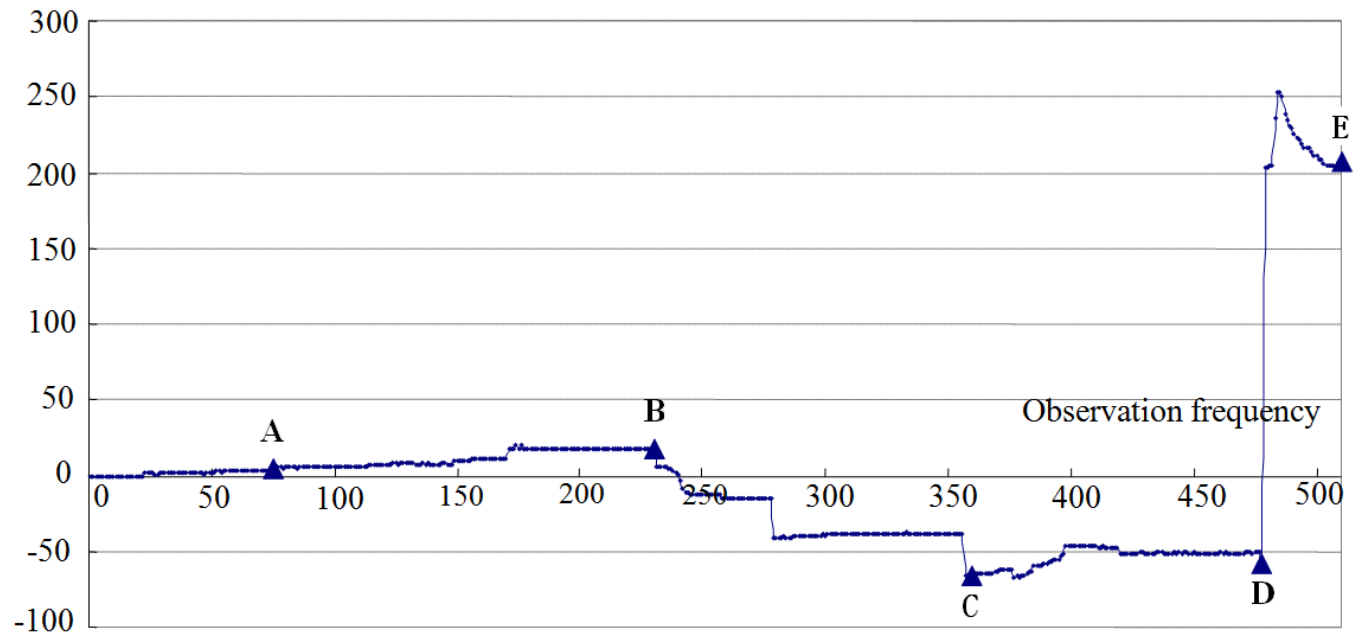

Figure 13. Stress change of observation points $60 \mathrm{~cm}$ away from mining boundary.

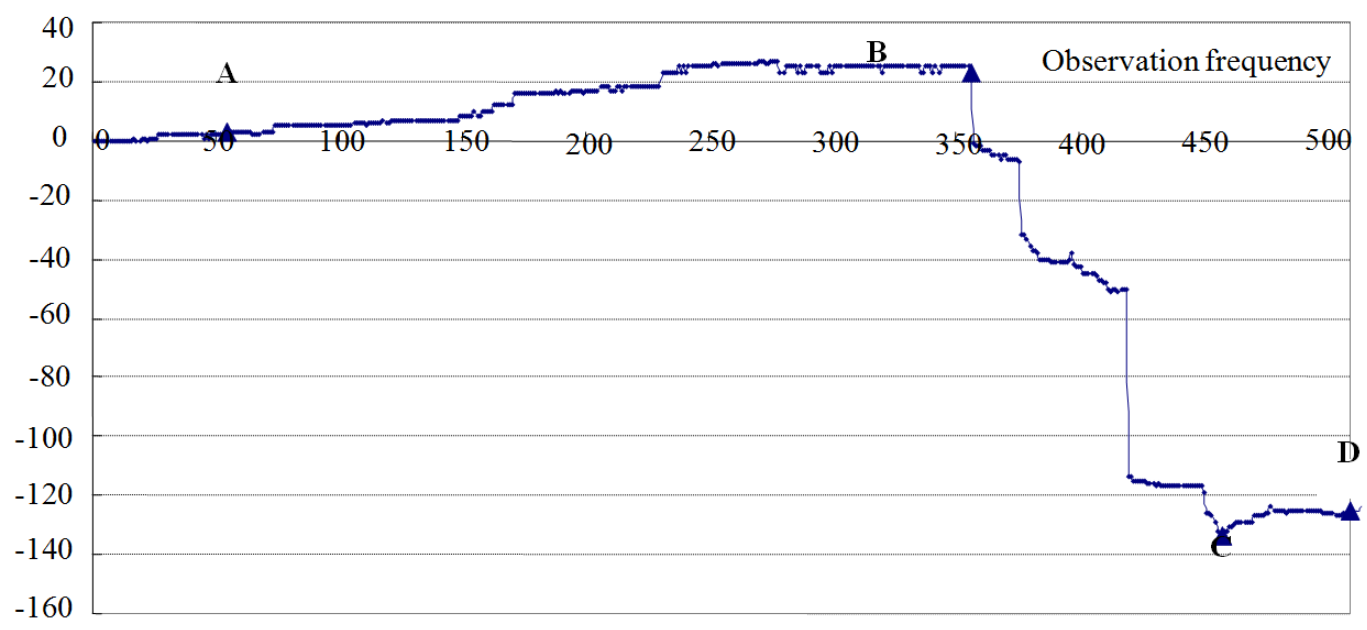

Figure 14. Stress change of observation points $75 \mathrm{~cm}$ away from mining boundary. 


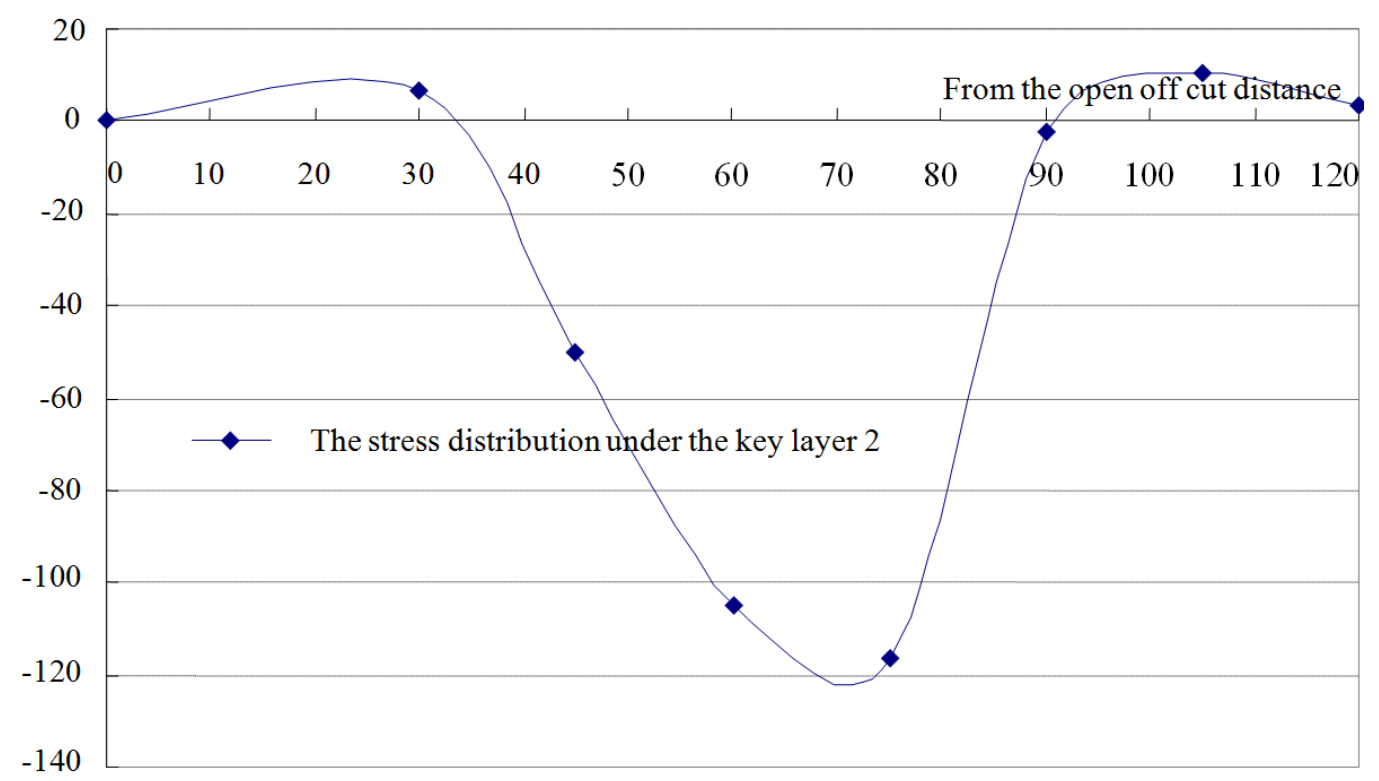

Figure 15. Stress distribution of observation points in key layer 2 when mining width is $80 \mathrm{~cm}$.

$\mathrm{O}$ - A stage: mining width is $0 \mathrm{~cm}$ to $30 \mathrm{~cm}$, belongs to primary rock stress,

A - B stage: mining width is $35 \mathrm{~cm}$ to $60 \mathrm{~cm}$, stress increases,

B - C stage: mining width is $65 \mathrm{~cm}$ to $75 \mathrm{~cm}$, stress decreases,

C - D stage: mining width is $80 \mathrm{~cm}$ to $105 \mathrm{~cm}$, stress remains the same,

$\mathrm{D}$ - E stage: mining width is $110 \mathrm{~cm}$, stress has a leap-growth and then decreases.

Unchanged remaining stress in C - D stage shows the abscission layer emerged between key strata 1 and key strata 2. All the weight of top layer was supported by key strata 2. According to primary roof breaking interval of key strata 2, key strata 2 breaking in D - E stage led to observed stress increase.

Compared with Figure 13, there was no C - D stage in Figure 8, which shows that stress distribution on key strata 1 between layered successive breakage and compound breakage are different.

Figure 14 shows that relationship between stress and mining width can be divided into four stages. Because that surface soil are unconsolidated, soil in caving arch keep synchronous movement with key strata 2 led to has no stress leap-growth during mining. Figure 15 shows the stress concentration and stress release emerged obviously on key strata 2 and load is following non-uniform distribution.

Comparing Figure 12 and Figure 14, stress decreased obviously without influence of confined unconsolidated aquifer. Mainly because of arching phenomenon emerged with the direct action of surface soil led the load act on key strata 2 far more less than the load induced by all weight of surface soil.

Key strata compound breakage was easy to emerge with the influence of confined unconsolidated aquifer. Key strata breakage type transform from successive breakage to compound breakage without influence of confined unconsolidated aquifer. Main reason is increasing mining width, arching phenomenon led the load act on key strata equivalent to the weight of soil in arch which far more less than the all soil.

With the influence of confined unconsolidated aquifer, the load act on key strata 2 remain the same along with mining step increasing. Relatively large load is the key factor led the synchronous compound breakage of key strata 1 and key strata 2 (Figure 16). Be different with above situation, without the influence of confined unconsolidated aquifer, the load act on key strata 2 decreased along with mining step increasing is the key factor led the unsynchronized of key strata. All above shows that load-transfer mechanism of confined unconsolidated aquifer is the direct reason of key strata breakage sequence transformation.

Key strata 2 and nearby rock strata are the load layer of key strata 1 when the key strata of surrounding rock compound breakage. Load on voussoir [9] beam structure consisting of breaking block increased obviously. Support break-off accident happened when retaining resistance of support less than the weight of unstabilized rock pillar. Retaining resistance of current fully mechanized mining supporter is about $500 \mathrm{KN}$ and can afford about 30 m unstabilized rock pillar. Mining under confined unconsolidated aquifer, as far as key strata of sur- 


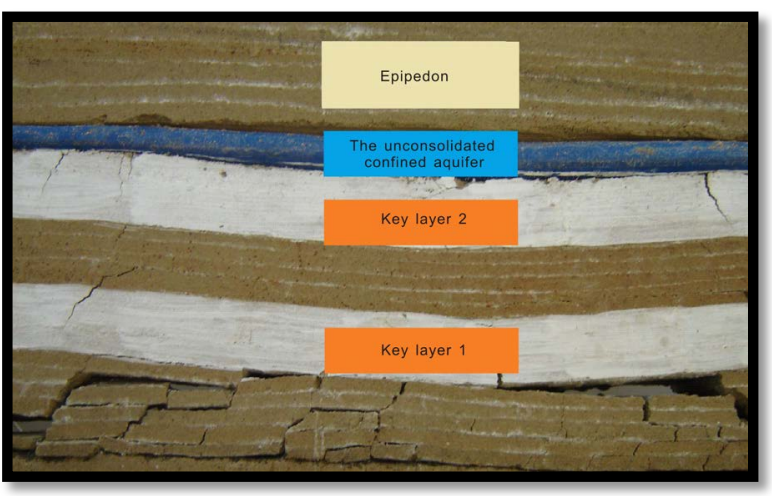

(a)

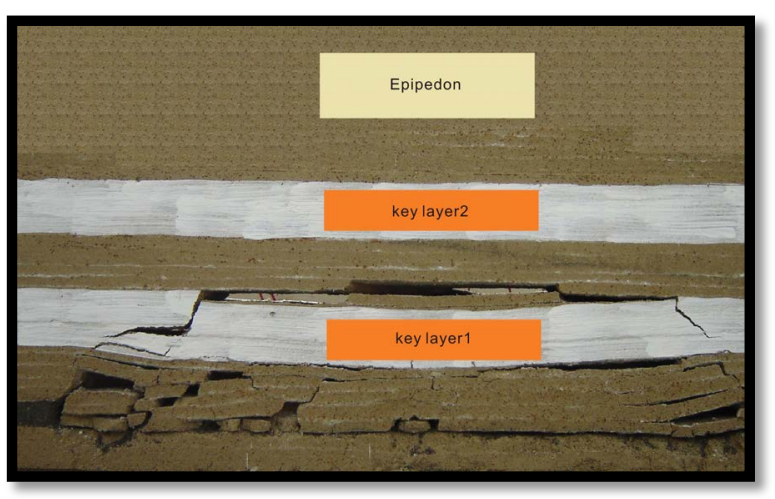

(b)

Figure 16. Test result of the unconsolidated confined aquifer influencing compound and fracture of key layer. (a) Key layer synchronization fracture in the condition of the unconsolidated confined aquifer; (b) Key layer fracture step by step in the condition of the non-unconsolidated confined aquifer.

rounding rock compound breakage, height of unstabilized rock pillar is far more than $30 \mathrm{~m}$ and support breakoff accident will happen inevitably.

\section{Conclusions}

Normally, the sequence of key strata break is the above key strata breaking off firstly, and load of the lower key strata suddenly increases in an instant of the above breaking, which is the basic reason of synchronous breaking with the above key strata.

As the unconsolidated confined aquifer exists between topsoil and the lower key strata, the load is generated by the topsoil all on the lower key strata, which is due to the influence of the unconsolidated confined aquifer. Topsoil acting on the lower key strata through the uniform load is the load transfer mechanism of loosely confined aquifer.

When the complex breaking key strata is in non-unconsolidated confined aquifer under the unconsolidated confined aquifer condition, the key strata turned layered successive breaking from original synchronous breaking and the load acting on the key strata is just the result of rock gravity within the height of caving arch, which is much smaller than the load generated by the thickness of topsoil.

As the key strata of overburden rock occurs compound breakage, there will be the instability of masonry beam structure and when the bracket support resistance is less than the weight of unstable rock pillars, it will cause the support crushing accident. Mining was done under the unconsolidated confined aquifer. Once compound breakage happened in the key strata and the bracket could not support the pressure of the instability of rock, mining crushing accidents will happen.

\section{Acknowledgements}

This study was financially supported by the National Natural Science Foundation of China (No. 41472235) and Anhui Provincial Natural Science Research Project in Colleges and Universities (KJ2014ZD11). The authors also thank the anonymous reviewers and editors for their constructive comments and suggestions on improving this manuscript.

\section{References}

[1] Xu, J.L., Wang, X.Z., Liu, W.T., et al. (2009) Effects of Primary Key Stratum Location on Height of Water Flowing Fracture Zone. Chinese Journal of Rock Mechanics and Engineering, 28, 380-385.

[2] Hang, Y., Zhang, G.L. and Yang, G.Y. (2009) Numerical Simulation of Dewatering Thick Unconsolidated Aquifers for Safety of Underground Coal Mining. Mining Science and Technology (China), 19, 312-316. http://dx.doi.org/10.1016/S1674-5264(09)60058-2

[3] Paradis, D. and Lefebvre, R. (2013) Single-Well Interference Slug Tests to Assess the Vertical Hydraulic Conductivity of Unconsolidated Aquifers. Journal of Hydrology, 478, 102-118. http://dx.doi.org/10.1016/j.jhydrol.2012.11.047 
[4] Sui, W.T., Cai, G.T. and Dong, Q.H. (2007) Experimental Research on Critical Percolation Gradient of Quicksand across Overburden Fissures Due to Coal Mining Near Unconsolidated Soil Layers. Chinese Journal of Rock Mechanics and Engineering, 26, 2084-2091.

[5] Xu, J.L., Cai, D. and Fu, K.L. (2007) Mechanism of Supports Crushing Accident and Its Preventive Measures during Coal Mining near Unconsolidated Confined Aquifer. Journal of China Coal Society, 32, 1239-1243.

[6] Tan, S.Y. and Wu, J.S. (2006) Cause Analysis of Water Bursting in 7114 Mining Face of 7 Coal Seam in Qidong Colliery. Journal of Coal Mining Technology, 11, 64-67.

[7] Xiong, X.Y. and Li, J.B. (2004) A Case Study of Support Break-Off at 1402(3) Fully Mechanized Mining Face. Coal Geology of China, 16, 34-37.

[8] State Coal Industry (1984) Mine Hydro-Geological Point of Order. Coal Industry Press, Beijing. (In Chinese)

[9] Xu, J.L. and Qian, M.G. (2000) Method to Distinguish Key Strata in Overburden Strata. Journal of China University of Mining and Technology, 29, 463-467.

[10] Lu, H.F., Yuan, B.Y. and Wang, L. (2011) Rock Parameters Inversion for Estimating the Maximum Heights of Two Failure Zones in Overburden Strata of a Coal Seam. Mining Science and Technology (China), 21, 41-47.

[11] Li, J.K., Wang, J.A. and Cui, S.H. (2005) Study on Pump Excavation Deformation and Fracture with Complex Stress under Deep Mining and High Pressure. Ground Pressure and Strata Control, 22, 12-13. (In Chinese)

[12] Xiao, T.Q., Wang, X.Y. and Zhang, Z.G. (2014) Stability Control of Surrounding Rocks for a Coal Roadway in a Deep Tectonic Region. International Journal of Mining Science and Technology, 24, 171-176. http://dx.doi.org/10.1016/j.ijmst.2014.01.005

[13] Guo, G.L., Zha, J.F., Miao, X.X., Wang, Q. and Zhang, X.N. (2009) Similar Material and Numerical Simulation of Strata Movement Laws with Long Wall Fully Mechanized Gangue Backfilling. Procedia Earth and Planetary Science, 1, 1089-1094. http://dx.doi.org/10.1016/j.proeps.2009.09.167

[14] Lu, A.H., Mao, X.B. and Liu, H.S. (2008) Physical Simulation of Rock Burst Induced by Stress Waves. Journal of China University of Mining and Technology, 18, 401-405. http://dx.doi.org/10.1016/S1006-1266(08)60084-X

[15] Li, Y.J., et al. (2014) A Physical and Numerical Investigation of the Failure Mechanism of Weak Rocks Surrounding Tunnels. Computers and Geotechnics, 61, 292-307. http://dx.doi.org/10.1016/j.compgeo.2014.05.017

[16] Bieniawski, Z.T. (1989) Rock Mass Classifications in Rock Engineering. John Wiley \& Sons, Inc, Hoboken.

[17] Xiao, T.Q., et al. (2011) Characteristics of Stress Distribution in Floor Strata and Control of Roadway Stability under Coal Pillars. Mining Science and Technology (China), 21, 243-247. http://dx.doi.org/10.1016/j.mstc.2011.02.016

[18] Liu, C.R. (2011) Distribution Laws of In-Situ Stress in Deep Underground Coal Mines. Procedia Engineering, 26, 909917. http://dx.doi.org/10.1016/j.proeng.2011.11.2255 
Scientific Research Publishing (SCIRP) is one of the largest Open Access journal publishers. It is currently publishing more than 200 open access, online, peer-reviewed journals covering a wide range of academic disciplines. SCIRP serves the worldwide academic communities and contributes to the progress and application of science with its publication.

Other selected journals from SCIRP are listed as below. Submit your manuscript to us via either submit@scirp.org or Online Submission Portal.
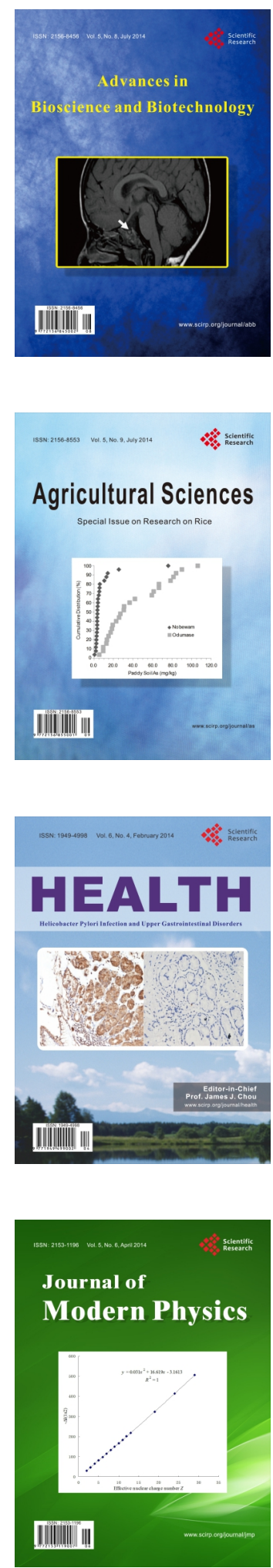
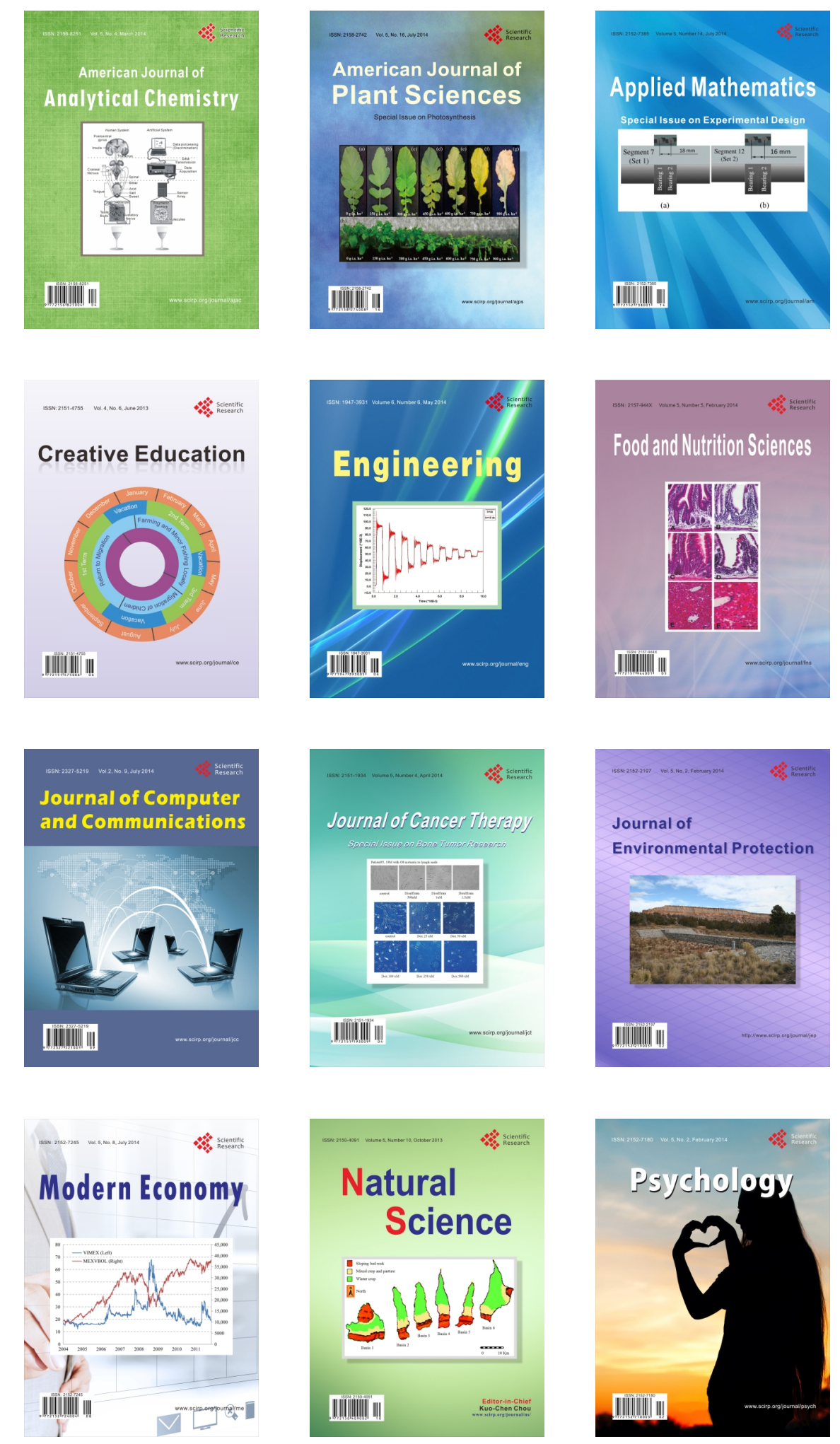